\title{
A comparative analysis for the criteria of higher education selection
}

\author{
Emine AKKAŞ \\ Kartal Anatolian High School, Istanbul, TURKEY \\ Mustafa Batuhan AYHAN* \\ Marmara University, Industrial Engineering Department, Ziverbey Campus, Kadikoy- \\ Istanbul, TURKEY \\ Article history \\ Received: \\ 05.07.2018 \\ Received in revised form: \\ 25.09.2018 \\ Accepted: \\ 26.09.2018 \\ Key words: \\ Higher Education Selection; \\ Criteria, Decision Making \\ Profession selection is one of the most important decisions for human \\ beings. Since the professions can generally be achieved via higher \\ education, determining the most proper higher education becomes an \\ important decision problem. In order to select the best higher education \\ program, there are various criteria to be considered. Hence the main \\ purpose of this study is to provide an analytical analysis of thirty three \\ criteria under the heading of three main criteria for higher education \\ selection. Then a case study was performed to find the relative weights \\ and ranking of these main and sub criteria at a high school for different \\ grade students. Depending on the comparison of weights and rankings of \\ different grade students, it was inferred that according to their age and \\ different grades, the students' preferences change during their \\ adolescence period regarding the higher education selection. This study \\ can be enhanced by applying multi criteria decision making techniques \\ such as, Analytical Hierarchy Process, to calculate the weights of the \\ main and sub criteria more analytically in the further steps.
}

\section{Introduction}

Today in modern societies, one of the most important choices within the life of a young person is to have a profession which is suitable for him/her. It is a crucial issue to choose the appropriate profession for an individual's and also public's life to be more useful. Because the person will choose not only the period that will shape his/her whole life but also social environment that $\mathrm{s} / \mathrm{he}$ will be in a relationship with. For this reason, making the right decision for the profession plays an important role to be happy and successful in the life (Pekkaya \& Çolak, 2013). A profession can be defined as a set of activities based on knowledge and skills that are achieved by individuals in order to earn their lives (Y1lmaz et al., 2012). Although profession can be achieved through a lifelong process, the last and most important education step for gaining the profession is the higher education period (Sarıkaya \& Khorshid, 2009).

Besides all other education steps, in the higher education phase a specific profession is learned. Therefore, higher education selection is important for profession choice. This 
selection depends on some factors like personal characteristics, surrounding environment, economic-social status, and high school education (Kılıç \& Ayhan, 2011; Sarıkaya \& Khorshid, 2009; Çelik \& Üzmez, 2014). While the students attending the high school education they may be directed to choose the appropriate profession through right guidance to them over years (Gati \& Saka, 1980). Hence they can decide which higher education to attend, in order to gain the best profession for them.

However, the profession choice and associatively higher education selection is complicated. Students should be aware of their expectations, capabilities, and requirements. These are related about with their self-perception of personality (Saunders et al., 2004). Self-perception means that individuals define their own emotions, attitudes, and other internal feelings from observations of their own behaviour (Bem, 1972). However, for teenagers, it is very difficult to have self-perceptions. Also, due to their physical, psychological aspects, and social aspects, their feelings, thoughts, and aims change rapidly during adolescence (Ince \& Khorshid, 2015). Since every student has different abilities (Sezer, 2010), their competencies for different professions vary. Therefore it is important to identify and increase their self-perceptions. For this reason students should be asked right questions that they are aware of their abilities. Relevant answers cause to discover their self-perception for students. This may help students to make preliminary preparation to lifelong career decision making process.

On the other side, even though the student knows his/her personal characteristics and information about the job, profession decision process is not completed yet. Because there are many steps like exams and tests that are needed to overcome to reach the desired profession. For example, there is a multiple choice exam for university entrance at the end of high school in Turkish educational system. Each department has a ranking score and for instance, studying medicine, engineering or law requires higher scores than other departments. Even if students know their capabilities, it is not enough in Turkey's educational system to attend for the proper higher education. As a result, it is also necessary to inform the students about the process of the education system in addition to informing them about their abilities (Sarikaya \& Khorshid, 2009).

Therefore the students should know both their capabilities and about the higher education system which will direct them to professions. Being aware of self capabilities is important to determine which criteria are important to select the best higher education. The literature was reviewed for the criteria that should be given importance when choosing a higher education. These criteria were classified in three main groups; University Selection, Profession Selection, and Socio Demographic Features. All possible sub criteria are identified into each main criterion to get more comprehensive results.

The main contributions of this article are in two-folds. Firstly a comprehensive investigation about the three main criteria and their sub criteria for higher education selection was made. Secondly this paper analyzed if there is a difference between the ranking of these main and sub-criteria with respect to different grades of high school students. This comparison enabled us to understand the changes occurring in the feelings and thoughts of adolescences during the high school education. By performing these two contributions, we can both detect the importance criteria for higher education selection and also analyze the changes occurring in the weights of criteria while the students are becoming older. In brief, the purpose of this study is to reveal how the students' preferences about higher education decision change while they are in high school. Based on this inference, the importance of guiding the students for their decision problem will be highlighted. The research sought answers to the following 
questions:

(1). What are the important criteria for higher education selection?

(2). What is the hierarchical structure of higher education selection criteria?

(3). Is there a difference between the weights of criteria among different grades of high school students?

The mapping of the remainder of this paper is as follows. Section 2 presents the methodology of the study including four sub-parts. Section 2.1 cites the relevant literature about criteria of higher education selection process. Section 2.2 lists and explains the Higher Education Selection Criteria including "University Selection", "Profession Selection", and "SocioDemographic Features". Section 2.3 gives information about the participants of the study. Section 2.4 analyzes the data and reveals the findings of this research study. Section 3 presents the concluding remarks and further studies.

\section{Methodology}

In order to answer the first research question and determine which criteria are important for the higher education selection, following key words were searched. These are; 'career choice', 'profession selection', 'university selection', 'higher education criteria', 'factors affecting higher education decision'. These key words were searched through 'Science Direct' and 'Google Scholar' e-databases. Although there are many other edatabases to search, this research study was limited with these e-databases which can be extended with others in further forthcoming studies. The search included empirical journal articles and book chapters. In addition, since the research would be performed in Turkey, national journals and conference proceedings published in Turkey were reviewed since 2000 . This time interval was selected intentionally because the preferences of the students had changed dramatically due to usage of internet technologies. The findings of literature review were presented at next section chronologically.

\subsection{Literature Review}

Altun (2000) determined that, nursing students choose nursing profession depending on certain reasons. These reasons are availability of job opportunities, being interested in nursing, parents' request, being a low-scored university department, favourable salary after graduation, comfortable working conditions, easy to study nursing. It is also important that the social prestige of the profession is in a position of honesty and responsibility (Altun, 2000).

Kuzgun (2004) defined that, the profession is the most important source of the person's identity and an area of activity that allows him to be respected, to establish relationships with others, to gain a place in society, and to come in useful in work.

Yanıkkerem et al., (2004) claimed that, choosing a profession is an important decision in an individual's life. When choosing the profession, an individual chooses a certain work and a certain lifestyle. S/he will be successful, productive, and happy on the chosen area of the profession in the direction of her/his talents, interests, and desires. If the individual chooses the profession at random without considering the characteristics, s/he becomes unsuccessful, inefficient, and unhappy. For this reason, when choosing a profession, it should be paid attention to the compatibility between his/her characteristics and the qualifications of the profession. 
Göksu and Güngör (2008) made a research study about university preference ranking. They determined three main criteria which are city, university, and department of university as a result of the questionnaires applied to high school students. Then they determined sub criteria for each of the three main criteria. Sub criteria for city are dormitory opportunities, scholarship, distance to hometown, social life, and costliness of city. Sub criteria for university are age of university, education in university, and social opportunities. Sub criteria for department are being interested in department, business opportunities, financial gain, and popularity of department. Weights of main and sub-criteria were calculated according to Fuzzy Analytical Hierarchy Process (F-AHP) approach. Since F-AHP method is widely used in multi criteria decision making problems, their approach well-fits to the problem of university preference ranking.

Ayhan and Atsay (2011) also studied higher education selection criteria. The hardest decision for a student who graduates from high school is to decide the university. There are many alternatives and all of them have different opportunities. If the student chooses university unsuitable for her/him, perhaps s/he will regret it throughout her/his life. In case of making the right choice, s/he will be happy in the work life. In order to contribute to such a critical decision process with a scientific study, university preference criteria were determined as university, department, scores taken from the higher education entrance exam and city. These criteria were detailed to provide a comparative analysis of how much the high school students were conscious and consistent about their decisions (Ayhan \& Atsay, 2011).

Kılıç and Ayhan (2011) mentioned about some more important factors and their importance levels in deciding the university. They grouped these factors in two classes representing the "University Selection Criteria" and "City Selection Criteria". Academic staff, foreign language, foreign connection, scholarship, popularity, and entrance scores criteria were found important for university selection criteria. Cultural and social aspects of city, cost of living conditions, distance to family, and climate conditions criteria were considered important for city of university.

Y1lmaz (2012) defined profession as not just a means of making money; but also primarily use of skills, self-actualization, and development. When a person does a job that gives pleasure to him, he does not feel tired; therefore he is not kept in a job stress. That is why, it is necessary to have career consciousness to make a right choice for students, when passing from high school education to university education. However, many of them do not have this consciousness or they cannot reach the necessary and correct data to make a right choice. As one of the misconceptions the Turkish exam system brings, university choice is usually decided according to the score obtained from the higher education entrance exams. As a result of this, many of the students have to study professions that they do not like or are not competent with.

In a recent article, "What comes to mind about career?" was asked to last grade students of a high school. Word of "career" caused different connotations in students and answers were collected under three main criteria. These criteria were determined as economy, status, and vocational/mental. The sub criteria for economy were money, good life, power, and having everything one needs. The sub criteria for status were profession, eminence, and a good job. The sub criteria for vocational/mental were happiness and success. In the same article the reasons that affect the career choice decision were also asked. According to the responses, participants were highly influenced by primarily family, then social media, when making career choices. And according to some participants only personal aims were effective in 
career choice (Tanhan \& Y1lmaz, 2017).

According to the review, there are many different criteria for higher education selection. Also, the articles approach the research area from different point of views. Many of them investigate the criteria for career choice. Some of them analyze the university preferences. Some others focus on the profession selection. However, the higher education selection can be nominated as a comprehensive research area including all aspects of these selection processes.

\subsection{Higher Education Selection Criteria}

As a result of literature review, all possible criteria for higher education selection were analyzed. These criteria were collected into three main criteria as; University Selection, Profession Choice, and Socio Demographic Features. Other sub criteria were clustered in these main criteria and they were organized in a hierarchical way as shown in Figure 1, which is also a response to both first and second research questions.

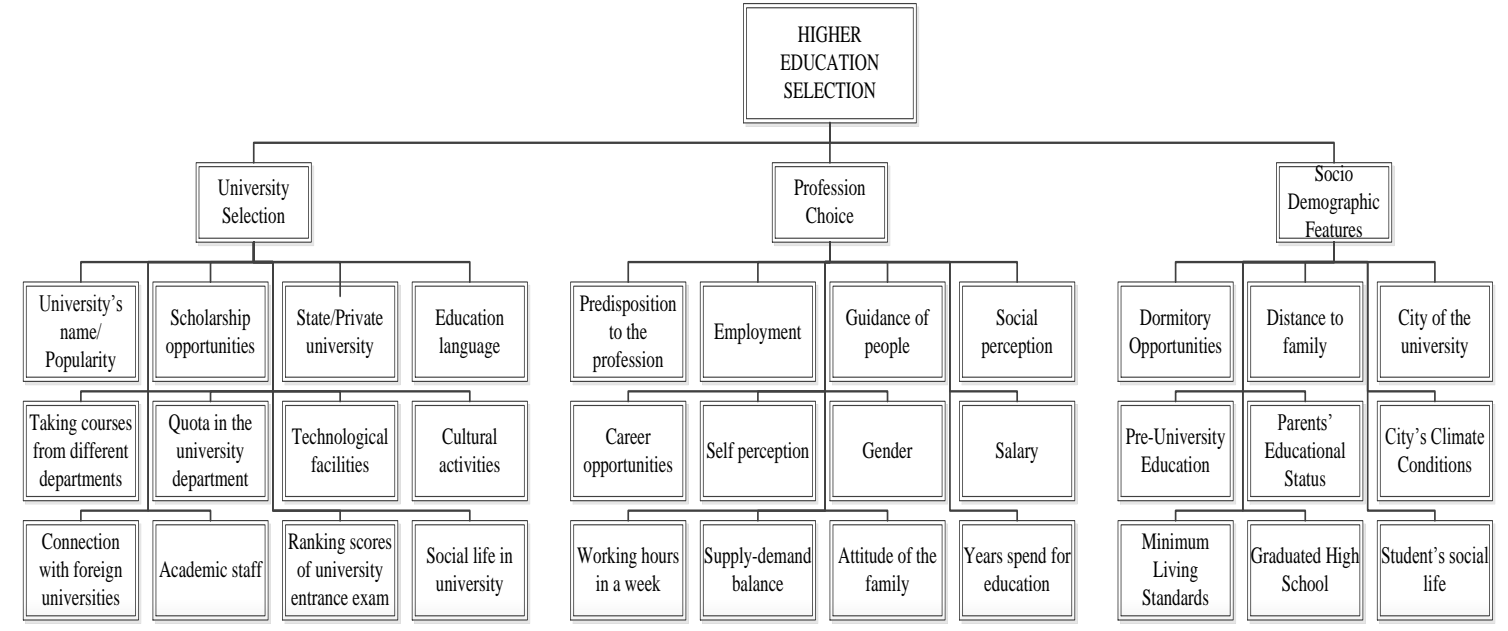

Figure 1.Hierarchical Representation of the Higher Education Selection Criteria

As shown in Figure 1, the first main criterion is "University Selection". All possible sub criteria for university selection were determined from literature review. 12 sub criteria were determined. "University's name/Popularity" is one of these sub criteria. Some students think that name of university and its reputation is important for employment, so they care for it "Scholarship opportunities" of a university is another sub criterion. Because, financial status of some families may not be enough to support children's education. "State/Private university" is also an important sub criterion. Because some private universities have high university fees and do not require high points from the university entrance exam. But state universities have low university fees and require high points. Some universities give education in national language and some of them give education in English. So "Education Language" is a sub criterion to be considered. Most of the universities allow to "Taking courses from different departments". This sub criterion is also important especially for the students who want to be trained in different areas. "Quota in the university department" is another sub criterion to be considered. Because if the number of students attending to the courses increase, then it can be hard to focus on and understand the lessons. In today's conditions, most of products in the world is technology-based so "Technological facilities" determine future orientations. Students need "Cultural activities" to relax in university. Students also give importance to "Connection with foreign universities" criterion to be informed about studies of universities in different countries. Some universities can have efficient staff of teachers so "Academic staff" criterion may be attractive for university 
selection. More preferred universities have higher scores in university exams. Hence, "Ranking scores of university entrance exams" criterion must be taken into consideration. "Social life in university" criterion represents social clubs, friend relationships.

The second main criterion is shown as "Profession Choice" in Figure 3.1. Related sub criteria were determined under it. "Predisposition to the profession" is one of the most important criteria. Because most of the people can succeed in a profession that they are interested in. "Employment" opportunities should be also considered. Some people prefer to behave like behaviour of people around or need experienced people's advices. This can be named as "Guidance of people". "Social perception" of someone can have a strong effect to determine the profession to be chosen. Everyone wants to make progress in his/her career. So "Career opportunities" is another important criterion. "Self-perception" is related to awareness of characteristics of him/herself and has influence in determining the profession. It can be considered that some professions are suitable for women and some professions are suitable for men. Therefore "Gender" criterion is also important. "Salary" has a big importance for decision of profession. Because money is the most important thing for the quality of life. Everyone wants to have less "Working hours in a week". It is also crucial to find work after university so "Supply-demand balance" of the profession and its job possibilities must be in available conditions. It means that, the demand of the profession should be at least greater than equal to the number of workers of that profession. "Attitude of the family" is about the responsibility to collect information about the professions and to help them identify these professions. "Years spend for education" is important for some people because different professions require different years for education. For example; it takes 6 years to study medicine in university. Beside this, law or teaching professions require 4 years of education in Turkey.

"Socio-Demographic Features" play an important role in higher education selection process. There are 9 sub criteria for this main criterion. A young teenager who graduates from high school often has to stay in dormitory during university education. So "Dormitory opportunities" is an important sub criterion for socio demographic features. Because staying away from family can be difficult for the student who is with an average age of 19 (Kılıç \& Ayhan, 2011). "Distance to family" is also important because it may cause unhappiness and stress if the student is far away from his family. Going home frequently can also cause financial problems for student. In Turkey, high-rated universities are usually in Istanbul, Ankara or Izmir. Hence "City of the university" is needed to consider. If "Pre-university education" of the student has passed efficiently, s/he gets higher points from university entrance exams. Educated and conscious parents guide their children to choose the appropriate profession. This criterion can be named as "Parent's educational status". It is generally expected from students to prefer areas with milder climate conditions than cold places for education. So "City's climate conditions" is a significant criterion. The financial possibilities of students are limited and for this reason, "Minimum living standards" of city should be affordable for students. "Graduated high school" adds extra points to university entrance exam points in Turkey's educational system. If a student has an active social life, $\mathrm{s} /$ he gives more importance to "Student's social life" criterion.

\subsection{Participants}

After all criteria were organized, a questionnaire was prepared based on the literature review and applied to a high school students in Istanbul in Turkey. This high school was selected due to its convenience to the researchers. One of the authors is a teacher at that high school. For international readers, the context of the study can be further mentioned by 
explaining the high school education system and entrance to higher education system in more detail. In Turkey, high schools consist of four grades; from year 9 to year 12. At the end of $12^{\text {th }}$ grade, students take Higher Education Entrance exam. According to points they take from this exam, they can apply for different higher education programs. The students who take higher points have the priority to be placed to the most preferred departments. Since it is an important step for their life, the high schools generally provide a guidance service by a psychological consultancy and guidance teacher. However, since the number of students is high, this experienced teacher can usually focus on the guidance of $12^{\text {th }}$ grade students. On the other side the $9^{\text {th }}$ grade students generally do not have this chance.

In order to respond to the third research question in this study, only the $9^{\text {th }}$ and $12^{\text {th }}$ grade students were selected to make the comparison of the criteria ranking. The survey consists questions about university selection, profession choice, socio demographic features, and their 33 sub criteria as mentioned above. The students were asked to score every sub criteria between 1 and 100. Then arithmetic mean was calculated for each sub criterion for both $9^{\text {th }}$ and $12^{\text {th }}$ grade students and shown in the Table 1 below.

Although the demographic characteristics of the participants asked on the questionnaire can be influential on students' profession selection, their demographic characteristics were not asked. This is because of the reason that, the participants were not analyzed individually. We took the average of their survey results to represent the result of grade's preference. That is, 204 questionnaires were performed by $9^{\text {th }}$ grade students but 186 of them were eligible. The results of these 186 eligible questionnaires were used to find out the $9^{\text {th }}$ grade's preference about higher education criteria. Similarly 154 out of 170 questionnaires were suitable to evaluate the $12^{\text {th }}$ grade's preference about these criteria. However, this study can be enhanced by analyzing the demographic characteristic of participants to make individual analysis for higher education selection in further studies.

\subsection{Data Analysis \& Findings}

After the questionnaires were analyzed, the average score of $j^{\text {th }}$ sub criterion under $i^{\text {th }}$ main criterion for $9^{\text {th }}$ grade students $\left(A_{C_{i j}}\right)$ is calculated as follows. For example; to find $A_{C_{1,1}}$ for $9^{\text {th }}$ grade students, all scores given for "university name/ popularity" criterion were summed up and divided by 186 which is the total number of meaningful questionnaires performed by $9^{\text {th }}$ grade students and found as in Equation 1;

$$
A_{C_{1,1}}=75.652
$$

$A_{C_{1,1}}$ : Average score for "university's name/popularity" sub criterion under "university selection" main criterion for $9^{\text {th }}$ grade students.

Similarly $B_{C_{1,1}}$ was calculated for $12^{\text {th }}$ grade students in the same way and found as in Equation 2;

$$
B_{C_{1,1}}=81.672
$$

$B_{C_{1,1}}$ : Average score for "university's name/popularity" sub criterion under "university selection" main criterion for $12^{\text {th }}$ grade students. 
Table 1. Average scores of each sub-criterion for both $9^{\text {th }}$ and $12^{\text {th }}$ grade students

\begin{tabular}{|c|c|c|c|}
\hline $\begin{array}{l}\text { Main } \\
\text { Criteria }\end{array}$ & Sub Criteria & $\begin{array}{l}\text { Average Scores for } 9^{\text {th }} \\
\text { Grades }\left(A_{C_{i, j}}\right)\end{array}$ & $\begin{array}{l}\text { Average Scores for } \\
12^{\text {th }} \text { Grades }\left(B_{C_{i, j}}\right)\end{array}$ \\
\hline \multirow{12}{*}{ 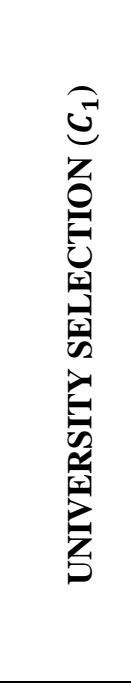 } & University's name/popularity $\left(C_{1,1}\right)$ & 75.652 & 81.672 \\
\hline & Scholarship opportunities $\left(C_{1,2}\right)$ & 72.663 & 75.695 \\
\hline & State-private university $\left(C_{1,3}\right)$ & 61.315 & 74.219 \\
\hline & Education language $\left(C_{1,4}\right)$ & 79.989 & 76.680 \\
\hline & $\begin{array}{l}\text { Taking courses from different departments } \\
\left(C_{1,5}\right)\end{array}$ & 70.624 & 70.414 \\
\hline & Quota in the university department $\left(C_{1,6}\right)$ & 63.878 & 59.039 \\
\hline & Technological facilities $\left(C_{1,7}\right)$ & 85.348 & 77.859 \\
\hline & Cultural activities $\left(C_{1,8}\right)$ & 83.519 & 72.117 \\
\hline & Connection with foreign universities $\left(C_{1,9}\right)$ & 82.613 & 76.789 \\
\hline & Academic staff $\left(C_{1,10}\right)$ & 89.414 & 91.305 \\
\hline & $\begin{array}{l}\text { Ranking scores of university entrance exams } \\
\left(C_{1,11}\right)\end{array}$ & 87.144 & 84.797 \\
\hline & Social life in university $\left(C_{1,12}\right)$ & 81.613 & 79.984 \\
\hline \multirow{12}{*}{ 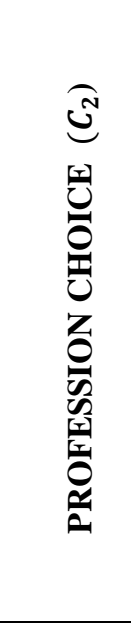 } & Predisposition to the profession $\left(C_{21}\right)$ & 93.039 & 92.055 \\
\hline & Employment $\left(C_{2,2}\right)$ & 75.840 & 75.109 \\
\hline & Guidance of people $\left(C_{2,3}\right)$ & 40.950 & 41.258 \\
\hline & Social perception $\left(C_{2,4}\right)$ & 44.050 & 46.492 \\
\hline & Career opportunities $\left(C_{2,5}\right)$ & 78.746 & 72.422 \\
\hline & Self-perception $\left(C_{2,6}\right)$ & 65.328 & 64.266 \\
\hline & Gender $\left(C_{2,7}\right)$ & 45.088 & 50.359 \\
\hline & Salary $\left(C_{2,8}\right)$ & 78.685 & 70.758 \\
\hline & Working hours in a week $\left(C_{2,9}\right)$ & 78.337 & 75.375 \\
\hline & Supply-demand balance $\left(C_{2,10}\right)$ & 71.796 & 70.633 \\
\hline & Attitude of the family $\left(C_{2,11}\right)$ & 64.481 & 55.914 \\
\hline & Years spent for education $\left(C_{2,12}\right)$ & 62.834 & 60.688 \\
\hline \multirow{9}{*}{ 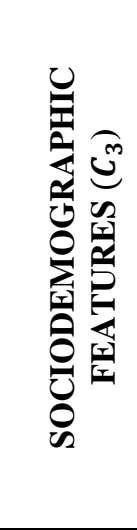 } & Dormitory opportunities $\left(C_{3,1}\right)$ & 81.155 & 72.188 \\
\hline & Distance to family $\left(C_{3,2}\right)$ & 64.840 & 55.789 \\
\hline & City of the university $\left(C_{3,3}\right)$ & 81.475 & 83.531 \\
\hline & Pre-university education $\left(C_{3,4}\right)$ & 74.818 & 71.219 \\
\hline & Parent's educational status $\left(C_{3,5}\right)$ & 44.674 & 38.141 \\
\hline & City's climate conditions $\left(C_{3,6}\right)$ & 48.381 & 48.742 \\
\hline & Minimum living standard of city $\left(C_{3,7}\right)$ & 57.199 & 53.227 \\
\hline & Graduated high school $\left(C_{3,8}\right)$ & 75.088 & 58.867 \\
\hline & Student's social life $\left(C_{3,9}\right)$ & 81.796 & 71.094 \\
\hline
\end{tabular}

According to averaged scores of each sub criterion, the weights of each main criterion were given in Table 2. For example, the weights of "University Selection" main criteria were calculated for $9^{\text {th }}$ and $12^{\text {th }}$ grade students as in Equation 3 and Equation 4, respectively. 
Table 2. Weights for Main Criteria

\begin{tabular}{|c|c|c|}
\hline Main Criteria & $\begin{array}{l}\text { Weights for 9th Grade } \\
\text { Students' }\left(W A_{C_{i}}\right)(\%)\end{array}$ & $\begin{array}{l}\text { Weights for 12th Grade Students' } \\
\qquad\left(W B_{C_{i}}\right)(\%)\end{array}$ \\
\hline University Selection $\left(C_{1}\right)$ & 39.86 & 40.94 \\
\hline Profession Choice $\left(C_{2}\right)$ & 34.12 & 34.48 \\
\hline $\begin{array}{l}\text { Socio Demographic Features } \\
\left(C_{3}\right)\end{array}$ & 26.02 & 24.58 \\
\hline Total & 100.00 & 100.00 \\
\hline
\end{tabular}

$W A_{C_{1}}=\frac{\sum_{j=1}^{12} A_{C_{1 j}}}{\sum_{j=1}^{12} A_{C_{1 j}}+\sum_{j=1}^{12} A_{C_{2 j}}+\sum_{j=1}^{9} A_{C_{3 j}}} * 100=$
$\frac{(75.652+72.663+\ldots+81.613)}{(75.652+72.663+\ldots+81.613)+(93.039+75.840+\cdots+62,834)+(81,155+64,840+\cdots+81,796)}=39.86 \%$

$$
\begin{gathered}
W B_{C_{1}}=\frac{\sum_{j=1}^{12} B_{C_{1 j}}}{\sum_{j=1}^{12} B_{C_{1 j}}+\sum_{j=1}^{12} B_{C_{2 j}}+\sum_{j=1}^{9} B_{C_{3 j}}} * 100= \\
(81.672+75.695+\ldots+79.984)
\end{gathered}
$$

$W A_{C_{1}}$ : Weight of "University Selection" main criteria for $9^{\text {th }}$ Grade Students

$W B_{C_{1}}$ : Weight of "University Selection" main criteria for $12^{\text {th }}$ Grade Students

As seen in Table 2, weights for main criteria have similar percentages for 9th and 12th grade students. University selection criterion's weight is $39.86 \%$, profession choice criterion's weight is $34.12 \%$, and socio demographic features criterion has a weight of $26.02 \%$ for $9^{\text {th }}$ grade students. On the other side, university selection criterion's weight is $40.94 \%$, profession choice has a weight of $34.48 \%$, and finally socio demographic features criterion has $24.58 \%$ for $12^{\text {th }}$ grade students. The weights of criteria are close to each other for different two grades. One of the reasons for this is that it takes a long time to change ideas. Therefore $9^{\text {th }}$ class students will be $12^{\text {th }}$ grade after three years and still continue to high school. Three years may be thought a short time to have fundamental changes of ideas. Another reason of having close weights for the main criteria can be influencing by each other's ideas during decision making process, because all students are in the same school. If we examine the weights of main criteria particularly, it is noticed that "university selection" is the most important criterion. Second important criterion is "profession choice" and the last one is "socio-demographic features". These results are in the same rank both for $9^{\text {th }}$ and $12^{\text {th }}$ grade students. Students think they can progress in career after deciding university according to socio demographic characteristics. They want to enter a good university firstly. Because university is the first step and focus point of career aim after graduating high school. So it can be said they give more importance to university selection.

In order to rank the sub criteria weights both for $9^{\text {th }}$ and $12^{\text {th }}$ grade students, it is better to take 5 sub criteria which have the highest averaged scores in every main criterion according to Table 1.

5 sub criteria with the highest averaged scores were listed for each main criterion in decreasing order, according to Table 1 for $9^{\text {th }}$ and $12^{\text {th }}$ grade students. Then, weights of the sub criteria were calculated for each sub criteria and shown in Table 3. 
Table 3. Weights and ranking of sub criteria for $9^{\text {th }}$ and $12^{\text {th }}$ grade students

\begin{tabular}{|c|c|c|c|c|c|c|c|}
\hline \multirow[b]{2}{*}{$\begin{array}{l}\text { Main } \\
\text { Criteria }\end{array}$} & \multirow[b]{2}{*}{ Rank } & \multicolumn{3}{|c|}{$9^{\text {th }}$ Grade Students } & \multicolumn{3}{|c|}{$12^{\text {th }}$ Grade Students } \\
\hline & & Sub criteria & Scores & $\begin{array}{c}\text { Weight } \\
\left(\mathrm{WA}_{\mathrm{C}_{\mathrm{ij}}}\right) \\
(\%)\end{array}$ & Sub Criteria & Scores & $\begin{array}{c}\text { Weight } \\
\left(\mathrm{WB}_{\mathrm{C}_{\mathrm{ij}}}\right) \\
(\%)\end{array}$ \\
\hline \multirow{5}{*}{ 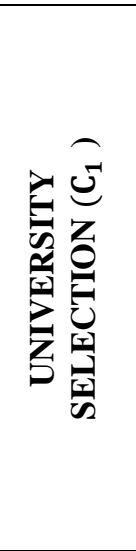 } & 1 & $\begin{array}{l}\text { Academic } \\
\text { Staff }\left(C_{1,10}\right)\end{array}$ & 89.414 & 9.58 & Academic Staff $\left(C_{1,10}\right)$ & 91.305 & 9.92 \\
\hline & 2 & $\begin{array}{l}\text { Ranking Scores of } \\
\text { University Entrance } \\
\text { Exams }\left(\mathrm{C}_{1,11}\right)\end{array}$ & 87.144 & 9.33 & $\begin{array}{l}\text { Ranking Scores of } \\
\text { University Entrance } \\
\text { Exams }\left(C_{1,11}\right)\end{array}$ & 84.797 & 9.21 \\
\hline & 3 & $\begin{array}{l}\text { Technological } \\
\text { Facilities }\left(\mathrm{C}_{1,7}\right)\end{array}$ & 85.348 & 9.14 & $\begin{array}{l}\text { University's } \\
\text { Name/Popularity } \\
\left(C_{1,7}\right)\end{array}$ & 81.672 & 8.87 \\
\hline & 4 & $\begin{array}{l}\text { Cultural Activities } \\
\left(\mathrm{C}_{1,8}\right)\end{array}$ & 83.519 & 8.94 & $\begin{array}{l}\text { Social Life in University } \\
\left(C_{1,12}\right)\end{array}$ & 79.984 & 8.69 \\
\hline & 5 & $\begin{array}{l}\text { Connection with } \\
\text { Foreign Universities } \\
\left(\mathrm{C}_{1,9}\right)\end{array}$ & 82.613 & 8.85 & $\begin{array}{l}\text { Technological Facilities } \\
\left(\mathrm{C}_{1,7}\right)\end{array}$ & 77.859 & 8.46 \\
\hline \multirow{5}{*}{ 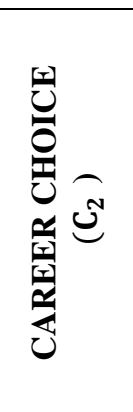 } & 1 & $\begin{array}{l}\text { Predisposition to the } \\
\text { Profession }\left(C_{2,1}\right)\end{array}$ & 93.039 & 11.64 & $\begin{array}{l}\text { Predisposition to the } \\
\text { Profession } \quad\left(C_{2,1}\right)\end{array}$ & 92.055 & 11.87 \\
\hline & 2 & $\begin{array}{l}\text { Career Opportunities } \\
\left(\mathrm{C}_{25}\right)\end{array}$ & 78.746 & 9.85 & $\begin{array}{l}\text { Working Hours in a } \\
\text { Week }\left(C_{2,9}\right)\end{array}$ & 75.375 & 9.72 \\
\hline & 3 & Salary $\left(C_{2,8}\right)$ & 78.685 & 9.85 & Employment $\left(\mathrm{C}_{2,2}\right)$ & 75.109 & 9.69 \\
\hline & 4 & $\begin{array}{l}\text { Working Hours in a } \\
\text { Week }\left(C_{2,9}\right)\end{array}$ & 78.337 & 9.80 & $\begin{array}{l}\text { Career Opportunities } \\
\left(\mathrm{C}_{2,5}\right)\end{array}$ & 72.422 & 9.34 \\
\hline & 5 & Employment $\left(\mathrm{C}_{2,2}\right)$ & 75.840 & 9.49 & Salary $\left(C_{1,10}\right)$ & 70.758 & 9.13 \\
\hline \multirow{5}{*}{ 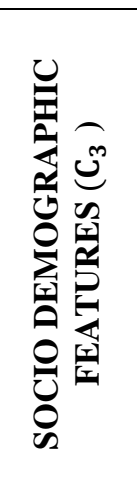 } & 1 & $\begin{array}{l}\text { Student's Social } \\
\text { Life }\left(C_{3,9}\right)\end{array}$ & 81.796 & 13.42 & $\begin{array}{l}\text { City of the University } \\
\left(\mathrm{C}_{3,3}\right)\end{array}$ & 83.531 & 15.11 \\
\hline & 2 & $\begin{array}{l}\text { City of the } \\
\text { University }\left(C_{3,3}\right)\end{array}$ & 81.475 & 13.37 & $\begin{array}{l}\text { Dormitory } \\
\text { Opportunities }\left(\mathrm{C}_{3,1}\right)\end{array}$ & 72.188 & 13.06 \\
\hline & 3 & $\begin{array}{l}\text { Dormitory } \\
\text { Opportunities }\left(\mathrm{C}_{3,1}\right)\end{array}$ & 81.155 & 13.32 & $\begin{array}{l}\text { Pre-University } \\
\text { Education }\left(\mathrm{C}_{3,4}\right)\end{array}$ & 71.219 & 12.88 \\
\hline & 4 & $\begin{array}{l}\text { Graduated High } \\
\text { School }\left(C_{3,8}\right)\end{array}$ & 75.088 & 12.32 & $\begin{array}{l}\text { Student's Social Life } \\
\left(C_{3,9}\right)\end{array}$ & 71.094 & 12.86 \\
\hline & 5 & $\begin{array}{l}\text { Pre-University } \\
\text { Education }\left(\mathrm{C}_{3,4}\right)\end{array}$ & 74.818 & 12.28 & $\begin{array}{l}\text { Graduated High School } \\
\left(C_{3,8}\right)\end{array}$ & 58.867 & 10.65 \\
\hline
\end{tabular}

For example weight of “Academic Staff" sub criterion for $9^{\text {th }}$ grade students $\left(W A_{C_{1,10}}\right)$ was calculated as in Equation 5.

$$
W A_{C_{1,10}}=\frac{A_{C_{11}}}{\sum_{j=1}^{12} A_{C_{1 j}}}=\frac{89.414}{75.652+72.663+\cdots+81.613} * 100=9.58 \%
$$

Similarly, weight of "Academic Staff" sub criterion for $12^{\text {th }}$ grade students $\left(W B_{C_{1,10}}\right)$ was calculated as in Equation 6.

$$
W A_{C_{1,10}}=\frac{A_{C_{11}}}{\sum_{j=1}^{12} A_{C_{1 j}}}=\frac{91.305}{81.672+75.695+\cdots+79.984} * 100=9.92 \%
$$

As seen in Table 3, there are significant differences among ranking of sub-criteria for each main criterion. For example, for "University Selection" main criterion $\left(C_{1}\right)$, first two sub 
criteria ranking are same for $9^{\text {th }}$ and $12^{\text {th }}$ grade students. It can be understood that students pay attention to Academic Staff and Ranking Scores of University Entrance Exams more than other sub criteria. The order of sub criteria changes after these two sub criteria. For $9^{\text {th }}$ grade students, the ranking of the criteria is Technological Facilities, Cultural Activities, and Connection with Foreign Universities. For $12^{\text {th }}$ grade students, the ranking of the criteria is University's Name/Popularity, Social Life in University, and Technological Facilities.

For "Profession Choice" main criterion $\left(C_{2}\right)$, Predisposition to the Profession is ranked first by both $9^{\text {th }}$ and $12^{\text {th }}$ grade students. The ranking of the sub criteria continues as Career Opportunities, Salary, Working Hours in a Week, and Employment for $9^{\text {th }}$ grade students. However sub-criteria ranking for $12^{\text {th }}$ grade students continues as, Working Hours in a Week, Employment, Career Opportunities, and Salary. All five sub criteria are same for both $9^{\text {th }}$ and $12^{\text {th }}$ grade students. However, the ranking is different.

Finally when the third main criterion "Socio Demographic Features" $\left(C_{3}\right)$ is analyzed, it can be seen clearly that all sub criteria are same for $9^{\text {th }}$ and $12^{\text {th }}$ grade students but ranking is different from each other. For $9^{\text {th }}$ grade students, the ranking of the sub criteria is; Student's Social Life, City of the University, Dormitory Opportunities, Graduated High School, and Pre-University Education. On the other side, for the $12^{\text {th }}$ grade students the ranking becomes; City of the University, Dormitory Opportunities, Pre-University Education, Student's Social Life, and Graduated High School. As a result of this analysis, depending on the different values and thoughts of high school students with different ages, the ranking of criteria can differ while considering the higher education selection process.

\section{Conclusion}

Career choice is one of the most important steps of a human being. In order to select the most proper profession, the individuals should decide which higher education program to attend. However, selecting the appropriate higher education is not straightforward especially for the teenagers. They should consider some criteria while selecting the higher education. In the literature, there are plentiful of different criteria considering higher education selection. However, as far as reviewed, there is not a comprehensive study encompassing many of these criteria in a hierarchical manner.

Therefore, one of the main contributions of this article is to provide a structural analysis of different criteria. According to the literature review and field analysis, thirty three criteria were found to be important and classified in three main criteria as named; "University Selection", "Profession Choice", and "Socio Demographic Features". Then in order to find the relative weights of these main and sub criteria a questionnaire was prepared and applied to a high school in Istanbul. The questionnaires were replied both by 9th and 12th grade students. They were asked to score every sub criterion between 1 and 100 for each main criterion. Depending on their scores, the weights of main criteria were calculated. In addition, for each main criterion, five sub criteria which have the highest averaged scores were taken and their relative weights were also calculated.

As another contribution of this study, the weights of main and sub criteria with respect to 9th and 12th grade students were calculated separately. Hence, the ranking of the criteria differs according to different grades. By comparing the weights and ranking of higher education selection criteria due to different grades, it can be inferred that, values and judgement of students can change according to their age and grade at high school. 
In conclusion, by performing this study, the research questions posed at the beginning of the study were answered. The important criteria for higher education selection were determined. These 33 criteria were represented as a hierarchical structure under three main criteria. In addition, it was found out that, weights of criteria for $9^{\text {th }}$ grade students were different from the weights of criteria for $12^{\text {th }}$ grade students. This result implies that, according to their age and different grades, the students' preferences change during their adolescence period regarding the higher education selection. By the help of this study, the importance of guidance service to the students is highlighted. Because, if the students can consult their counselling teachers, they can be directed more correctly. Moreover, by analyzing the criteria weights and average scores, the universities in Turkey can be aware of which criteria are important for high school students. Hence, they can re-organize themselves and try to attract the students' attention according to these criteria.

Although this study releases a comprehensive analysis about the higher education selection criteria, it can be enhanced in further studies. The literature can be searched by using different e-databases and including studies published by the foreign scholars. By performing a comparison analysis, we can detect different higher education selection criteria between various cultures. Similarly, the demographic characteristic of the participants can also be analyzed and compared. So that, we can find out if there is a significant difference between the students with different demographic characteristic regarding the higher education selection criteria.

On the other hand, by applying some mathematical technics, the study can be improved. For example, weights of the main and sub criteria can be calculated more precisely by using one of the multi-criteria decision making methods (i.e. Analytical Hierarchy Process). In addition consistency analysis can be done for the preference ranking of the students. Moreover, depending on this consistency analysis, another study can be performed to check the consistencies of different grade students.

\section{Acknowledgments}

The authors would like to acknowledge the voluntary participation from the high school students for the questionnaires performed

\section{Author Contributions}

Emine AKKAŞ and Mustafa Batuhan AYHAN contributed to the design of the methodology. Emine AKKAŞ performed the questionnaires, collected, and analyzed the data. Emine AKKAŞ and Mustafa Batuhan AYHAN contributed to the writing of the paper.

\section{References}

Altun, İ. (2000, March). Personal values of Kocaeli school of health students and factors affecting occupation selections. Paper presented at $1^{\text {st }}$ International $\& 8^{\text {th }}$ National Nursing Congress, Antalya, Turkey.

Ayhan, M. B. and Atsay, F. (2011, May). Comparative analysis of prioritization of preference criteria for higher education.Paper presented at $1^{\text {st }}$ International Higher Education Congress: New Trends and Issues, (pp. 1724-1731), Istanbul.

Bem, D. J. (1972). Self-Perception Theory. In L. Berkowitz (Ed.). Advances in Experimental Social Psychology, 6. 1-62. New York: Academic Press.

Çelik, N. and Üzmez, U. (2014). Evaluation of university students' affecting factors choice of profession. Electronic Journal of Occupational Improvement and Research, 2(1), 94105. 
Gati, I. and Saka, N. (1980). High school students' career-related decision-making difficulties. Journal of Vocational Behaviour, 16(3), 282-298.

Göksu, A. and Güngör, İ. (2008). Fuzzy Analytic Hierarchy Process and its application of university preference ranking. Suleyman Demirel University the Journal of Faculty of Economics and Administrative Sciences, 13(3), 1-26.

İnce, S. and Khorshid, L. (2015). Determination of Factors Affecting Career Choices of Nursing Students. Journal of Anatolia Nursing and Health Sciences, 18(3), 163-171.

Kılıç, H. S. and Ayhan M. B. (2011, May). Analyzing the factors in the university selection based on AHP: A case study among the students of Marmara University. Paper presented at $1^{\text {st }}$ International Higher Education Congress: New Trends and Issues, (pp. 1839-1844), Istanbul.

Kuzgun, Y. (2004). Introduction to vocational guidance and counselling. Ankara: Nobel Publishing, ISBN: 6051331041.

Pekkaya, M. and Çolak, N. (2013). Determining the priorities of ratings via AHP for the factors that effects in choosing profession for the university students. International Journal of Social Science, 6(2), 797-818.

Sarıkaya, T. and Khorshid, L. (2009). Examining the factors affecting the occupation choice of university students: Occupation selection of university students. The Journal of Turkish Educational Sciences, 7(2), 393-423.

Saunders, J., Davis, L., Williams, T. and Williams, J. H. (2004). Gender differences in self perceptions and academic outcomes: A study of African American high school students. Journal of Youth and Adolescence, 33(1), 81-90.

Sezer, Ö. (2010). The relationship between adolescents' self-perception, parental attitudes, and some other variables. The Journal of Education Faculty of Yuzuncu Yll University, 7(1), 1-19.

Tanhan, F. and Y1lmaz, Ü. (2017). The Examination of the effects of family and social media on students' career choices (A focus group work). The Journal of Social Sciences Institute, 1(35), 161-174.

Yanıkkerem, E., Altınparmak, S. and Karadeniz, G. (2004). Factors affecting young people's career choice and their and self-esteem. Nursing Forum, 7(2), 61- 62.

Yılmaz, A., Dursun, B., Pektaş, K. and Altay, A. (2012). Career choices of university students in terms of demographic characteristics: The sample of Pinarhisar Vocational Collage Electronic. Journal of Vocational Colleges, 2(2), 9-21.

Y1lmaz V. (2012). The effects of stress on individual performance: A research on staff employed in a private furniture factory. Unpublished master's thesis, Ufuk University, Istanbul, Turkey. 